\title{
Pendugaan Umur Simpan Tepung Jamur Tiram Putih (Pleurotus ostreatus) Pada Kemasan Plastik Polietilen dengan Metode Akselerasi
}

\section{Shelf Life of White Oyster Mushroom (Pleurotus ostreatus) Flour in Polyethylene Plastic Packaging with the Arrhenius Method}

\section{Sussi Astuti*, Sri Setyani, Suharyono, dan Muhammad Nurreza H}

Jurusan Teknologi Hasil Pertanian Fakultas Pertanian Universitas Lampung

*E-mail: sussiastuti67@gmail.com

\begin{abstract}
The aim of the research was to determine the shelf life of white oyster mushroom flour in polyethylene plastic packaging with the Arrhenius method. The study was arranged descriptively with two replications. White oyster mushroom flour was stored at three storage temperature conditions, i.e. $30^{\circ} \mathrm{C}, 40^{\circ} \mathrm{C}$ and $50^{\circ} \mathrm{C}$ in polyethylene plastic packaging with a thickness of $0.03 \mathrm{~mm}$ and stored for one month (28 days). Observations were made on water content, levels of free fatty acids, protein content, flavour and color of white oyster mushroom flour every once a week i.e. on days $0,7,14,21$ and 28. The data obtained were used to determine the shelf life of white oyster mushroom flour using acceleration (accelerated storage) method with Arrhenius equation model using Microsoft Excel software. The results showed that the shelf life of white oyster mushroom flour in polyethylene plastic packaging thickness of $0.03 \mathrm{~mm}$ using the Arrhenius method was set at a temperature of $30^{\circ} \mathrm{C}$ based on the parameters of the zero reaction protein content, which was 130.67 days (4.3 months). White oyster mushroom flour in polyethylene plastic packaging thickness of $0.03 \mathrm{~mm}$ during storage temperature of $30^{\circ} \mathrm{C}, 40^{\circ} \mathrm{C}$, and $50^{\circ} \mathrm{C}$ tends to decrease protein content, color and aroma, but experience an increase in free fatty acid levels. White oyster mushroom flour in polyethylene plastic packaging at $30^{\circ} \mathrm{C}$ tends to increase in water content during storage, and decreased water content at $40^{\circ} \mathrm{C}$ and $50^{\circ} \mathrm{C}$.
\end{abstract}

Keywords: Acceleration Method, Polyethylene Plastic Packaging, Shelf Life, White Oyster Mushroom Flour

Disubmit : 12 Januari 2019 ; Diterima: 20 Maret 2019, Disetujui : 29 April 2019

\section{PENDAHULUAN}

Jamur tiram (Pleurotus sp.) merupakan salah satu jenis sayuran yang banyak dikonsumsi oleh masyarakat karena rasanya lezat dan memiliki nilai gizi tinggi. Jamur tiram putih (Pleurotus ostreatus) memiliki nilai ekonomis dan ekologi serta dapat dijadikan sebagai obat. Jamur tiram putih memiliki waktu tumbuh paling pendek jka dibandingkan jamur lain (Sánchez, 2010). Jamur tiram putih banyak dibudidayakan oleh para petani, sehingga keberadaan jamur tiram putih sangat melimpah. Menurut Dinas Tanaman Pangan dan Hortikultura (2015) produksi jamur tiram putih pada tahun 2014 di Lampung sebanyak 330.550 kuintal, sedangkan produksi jamur tiram di Bandar Lampung sebanyak 49.658 kuintal.

Jamur tiram putih mengandung protein sebesar 27\%, lemak sebesar 1,6\%, karbohidrat sebesar 58\%, abu sebesar 9,3\% (Cahyana, Y.A., Muchrodji, 1999). Menurut Arianto (2009), jamur tiram putih mudah mengalami kerusakan setelah dipanen, jamur tiram mudah berubah warna dan keriput. Hal ini disebabkan jamur tiram memiliki kadar air cukup tinggi yaitu sebesar $86,6 \%$. Oleh karena itu perlu dilakukan suatu usaha 
untuk memperpanjang daya simpan jamur tiram putih, dengan mengolah jamur tiram menjadi bentuk bubuk atau tepung. Menurut Widyastuti and Istini (2004), proses pengeringan jamur tiram dan mengolahnya menjadi tepung jamur tiram bertujuan untuk mengurangi kadar air jamur tiram. Menurut Ardiansyah et al (2014), tepung jamur tiram merupakan salah satu bahan makanan yang memiliki kadar protein yang cukup tinggi dengan komposisi sebagai berikut : kadar air sebesar 7,29, kadar protein sebesar 17,75\%, kadar abu sebesar $8,26 \%$, kadar lemak sebesar 1,97\%, dan kadar karbohidrat sebesar 71,28\%. Tepung jamur tiram putih merupakan bahan pangan yang termasuk jenis bahan pangan kering. Tepung jamur tiram dapat diaplikasikan untuk sosis (Rus'an, 2007), nugget (Laksono et al, 2012), produk olahan daging tiruan, dan kerupuk (Nurany et al, 2015).

Sampai saat ini belum diketahui masa simpan tepung jamur tiram putih, sehingga diperlukan uji pendugaan umur simpan dalam pengemasan yang baik. Dua faktor yang sangat mempengaruhi masa simpan bahan pangan adalah pengemasan dan suhu. Pengemasan merupakan cara yang paling mudah dalam mempertahankan mutu produk. Menurut Syarief, R., S. Santausa (1989), kemasan dapat mencegah atau mengurangi kerusakan, melindungi bahan yang ada di dalamnya dari pencemaran serta gangguan fisik seperti gesekan, benturan dan getaran. Berdasarkan penelitian Susilo (2012), umur simpan bahan makanan campuran tepung sukun dan tepung kacang benguk germinasi yang dikemas dalam kemasan plastik polietilen memiliki umur simpan selama 319,2 hari. Hal ini menunjukkan bahwa plastik polietilen merupakan salah satu jenis kemasan yang dapat meningkatkan umur simpan produk.

Kemasan plastik memiliki beberapa keunggulan yaitu harganya murah, lebih ringan, praktis serta mudah diperoleh. Pengemasan dapat menjaga kualitas tepung seperti kadar air, aktifitas air, kerusakan zat gizi, dan menambah masa simpan tepung (Arpah, 2001). Menurut (Syarief, R., S. Santausa, 1989), penggunaan plastik dalam pengemasan bahan pangan disebabkan sifatnya yang fleksibel, mudah dibentuk, mempunyai adaptasi yang tinggi terhadap produk, tidak korosif serta mudah dalam penanganannya. Hafriyanti dan Hidayati (2008) menyatakan bahwa kemasan plastik melindungi produk dari perubahan kadar air karena bahan kemasan dapat menghambat terjadinya penyerapan uap air dari udara. Polietilen memiliki sifat-sifat yang menguntungkan antara lain mudah dikelim oleh panas, fleksibel, permeabilitas uap air dan oksigen rendah, dapat digunakan dalam penyimpanan beku $\left(-50^{\circ} \mathrm{C}\right)$, sehingga kemasan polietilen dapat memperpanjang umur simpan suatu bahan pangan. Plastik HDPE memiliki permeabilitas uap air sebesar $130 \mathrm{cc} /$ detik.cm ${ }^{2}, \mathrm{cmHg}$ pada suhu $25^{\circ} \mathrm{C}$, sedangkan permeabilitas $\mathrm{O}_{2}$ sebesar $10,6 \mathrm{cc} /$ detik. $\mathrm{cm}^{2}, \mathrm{cmHg}$ pada suhu $30{ }^{\circ} \mathrm{C}$. Plastik LDPE memiliki permeabilitas uap air sebesar $800 \mathrm{cc} /$ detik.cm ${ }^{2}$, cmHg pada suhu $25{ }^{\circ} \mathrm{C}$, sedangkan permeabilitas $\mathrm{O}_{2}$ plastik polietilen lebih besar dibandingkan polipropilen. Permeabilitas gas plastik polietilen sebesar $55 \mathrm{cc} / \mathrm{detik}_{\mathrm{cm}}{ }^{2}$, cmHg pada suhu $30^{\circ} \mathrm{C}$ (Ashley, 1985).

Secara garis besar, umur simpan dapat ditentukan dengan menggunakan metode konvensional (extended storage studies, ESS) dan metode Accelerated Shelf Life Testing (ASLT) (Syarief, R., S. Santausa, 1989). Pendugaan umur simpan dengan metode ASLT dilakukan dengan cara penyimpanan produk pangan pada lingkungan yang menyebabkan produk cepat rusak, baik pada kondisi suhu atau kelembaban ruang penyimpanan yang lebih tinggi (Kusnandar, 2006). Pada metode ini, kondisi penyimpanan diatur di luar kondisi normal sehingga produk lebih cepat rusak dan penentuan umur simpan dapat ditentukan (Arpah dan Syarief, 2000). Selain itu, penggunaan metode akselerasi harus disesuaikan dengan keadaan dan faktor yang mempercepat kerusakan produk yang dikemas (Ellis, 1994).

Reaksi penurunan mutu bahan pangan selama penyimpanan diakibatkan oleh reaksi kimia pada makanan yaitu reaksi ordo nol dan satu. Tipe kerusakan pangan yang mengikuti model reaksi ordo nol adalah degradasi enzimatis (buah dan sayuran segar, beberapa pangan beku); reaksi pencoklatan non-enzimatis (bijibijian kering dan produk susu kering); dan reaksi oksidasi lemak (peningkatan ketengikan pada snack, makanan kering dan pangan beku). Tipe kerusakan bahan pangan yang termasuk reaksi ordo satu adalah (1) ketengikan (minyak salad dan sayuran kering); (2) pertumbuhan mikroorganisme (ikan dan daging, serta 
kematian mikoorganisme akibat perlakuan panas); (3) produksi off flavor oleh mikroba; (4) kerusakan vitamin dalam makanan kaleng dan makanan kering; dan (5) kehilangan mutu protein (makanan kering) (Labuza, 2000). Tepung jamur tiram putih dapat mengikuti model reaksi ordo nol maupun ordo satu. Menurut Ardiansyah, et al (2014) tepung jamur tiram memiliki kadar lemak sebesar 1,97\%, sehingga tepung jamur tiram putih mudah mengalami kerusakan berupa off flavor akibat oksidasi lemak. Selain itu, kerusakan akibat suhu diduga mengakibatkan perubahan warna dan penurunan mutu protein pada tepung jamur tiram putih sehingga terjadi reaksi pencoklatan dan menurunkan penerimaan oleh konsumen.

Pada penelitian ini, penentuan umur simpan dengan pendekatan Arrhenius terhadap tepung jamur tiram putih dilakukan dalam tiga suhu yang berbeda yaitu $30^{\circ} \mathrm{C}, 40^{\circ} \mathrm{C}$, dan $50^{\circ} \mathrm{C}$. Pengamatan dilakukan setiap 7 hari selama 28 hari penyimpanan terhadap parameter yang mempengaruhi yaitu kadar air, kadar asam lemak bebas, kadar protein, serta aroma dan warna tepung jamur tiram putih. Menurut Syarif dan Halid (1993), pada produk pangan kering seperti bubuk dan tepung, parameter penurunan mutu didasarkan pada parameter yang paling sensitif terhadap mutu suatu produk. Oleh karena itu, diperlukan penelitian untuk menentukan umur simpan tepung jamur tiram putih dalam kemasan plastik polietilen dengan metode Arrhenius.

\section{METODE PENELITIAN}

Bahan utama yang digunakan dalam penelitian adalah jamur tiram putih (Pleurotus ostreatus) yang diperoleh dari salah satu pengusaha jamur tiram putih di Desa Sidosari, Kec. Natar, Lampung Selatan. Bahan kemasan yang digunakan dalam penelitian adalah kemasan plastik polietilen dengan ketebalan $0.03 \mathrm{~mm}$. Bahan kimia yang digunakan untuk analisis adalah aquades, asam sulfat pekat $\left(\mathrm{H}_{2} \mathrm{SO}_{4}\right)$ p.a (Merck), natrium hidroksida $(\mathrm{NaOH}), \mathrm{K}_{2} \mathrm{SO}_{4}, \mathrm{HgO}, \mathrm{HCL} 0,02 \mathrm{~N}, \mathrm{H}_{3} \mathrm{BO}_{3}, \mathrm{Na}_{2} \mathrm{CO}_{3}$, etanol 96\%, indikator metil merah dan metil biru $0,2 \%$, indikator fenolftalein.

Peralatan yang digunakan untuk pembuatan tepung jamur tiram putih adalah pisau stainless steel, talenan, blender, timbangan digital, timbangan analitik, baskom plastik, loyang, termometer, kertas saring, dan ayakan 80 mesh. Sedangkan peralatan untuk analisis adalah cawan porselen, cawan alumunium, oven, inkubator, desikator, spatula, neraca analitik, labu Kjeldahl, alat-alat gelas, dan seperangkat alat uji sensori.

Penelitian dilakukan dengan menggunakan metode deskriptif. Tiga perlakuan penyimpanan tepung jamur tiram putih yaitu suhu $30^{\circ} \mathrm{C}, 40^{\circ} \mathrm{C}$ dan $50^{\circ} \mathrm{C}$ dengan dua kali ulangan. Tepung jamur tiram putih dikemas menggunakan kemasan plastik polietilen. Penyimpanan jamur tiram putih dilakukan selama satu bulan (28 hari). Pengujian dilakukan terhadap kadar air, kadar asam lemak bebas, kadar protein, warna dan aroma tepung jamur tiram putih setiap satu minggu sekali yaitu pada hari ke $0,7,14,21$ dan 28 . Data hasil pengujian digunakan untuk menentukan umur simpan dengan menggunakan metode akselerasi (penyimpanan dipercepat) dengan model persamaan Arrhenius (kinetika reaksi) menggunakan software Microsoft Excel (Kusnandar et $a l, 2010)$.

Pelaksanaan Penelitian terdiri dari tahap pembuatan tepung jamur tiram putih, tahap penyimpanan tepung jamur tiram putih, tahap analisis dan perhitungan umur simpan tepung jamur tiram putih.

Pembuatan Tepung Jamur Tiram Putih dilakukan dengan metode Ardiansyah et al (2014). Jamur tiram putih disortir lalu diambil bagian tudung jamur, ditimbang sebanyak $15 \mathrm{~kg}$, kemudian dilakukan pencucian sebanyak 2 kali, selanjutnya dipotong memanjang dengan ukuran 2-3 cm. Potongan jamur tiram putih diletakkan dalam loyang yang telah dialasi alumunium foil dan dikeringkan dengan oven (suhu $45 \mathrm{oC}$ selama 24 jam). Setelah itu, jamur tiram putih kering digiling dengan blender selama 5 menit kemudian diayak menggunakan ayakan 80 mesh, sehingga diperoleh tepung jamur tiram putih yang digunakan sebagai bahan utama penelitian.

Tahap Penyimpanan dan Pengamatan Tepung Jamur Tiram Putih. Penyimpanan tepung jamur tiram putih dilakukan dengan cara dikemas dalam plastik polietilen, kemudian disimpan pada suhu $30^{\circ} \mathrm{C}, 40^{\circ} \mathrm{C}$ dan $50^{\circ} \mathrm{C}$ dengan menggunakan tiga oven untuk setiap suhu penyimpanan. Pada setiap suhu disiapkan sampel 
sebanyak 10 bungkus dengan berat setiap bungkus sebanyak $20 \mathrm{~g}$. Tepung jamur tiram putih disimpan selama satu bulan (28 hari) di dalam oven. Setiap minggu atau pada hari ke 0, 7, 14, 21 dan 28, terhadap sampel pada setiap suhu penyimpanan diamati kadar air (AOAC, 2005), kadar asam lemak bebas Sudarmadji (1997), kadar protein (AOAC, 2005), dan uji sensori (aroma dan warna) (S. Koswara, 2004).

Uji sensori yang dilakukan yaitu membandingkan antara tepung jamur tiram putih yang mengalami perlakuan penyimpanan dengan kontrol. Kontrol merupakan tepung jamur tiram putih yang tidak mengalami perlakuan penyimpanan dan proses pembuatannya dilakukan sehari sebelum tepung jamur tiram putih diuji aroma dan warnanya. Skor yang digunakan pada aroma tepung jamur tiram putih antara lain 7 yaitu normal (sama dengan kontrol), 6 yaitu normal (diduga ada off flavor tetapi belum tercium), 5 yaitu normal (off flavor mulai tercium tetapi sangat lemah), 4 yaitu off flavor tercium lemah, 3 yaitu off flavor tercium jelas, 2 yaitu off flavor tercium kuat atau tengik, dan 1 yaitu off flavor tercium sangat kuat atau sangat tengik. Skor yang digunakan pada warna tepung jamur tiram putih antara lain 7 yaitu normal atau sama dengan kontrol (putih kecoklatan), 5 yaitu normal sedikit lebih coklat, 3 yaitu warna lebih coklat, dan 1 yaitu warna coklat gelap. Skor uji sensori aroma dan warna tepung mulai tidak diterima oleh panelis yaitu 3 yang dapat digunakan sebagai parameter kritis untuk penentuan (perhitungan) umur simpan tepung jamur tiram putih (Koswara dan Kusnandar, 2004).

Tahap Analisis dan Penentuan Umur Simpan Tepung Jamur Tiram Putih. Nilai rata-rata dari data pengamatan kadar air, kadar asam lemak bebas, kadar protein, dan uji sensori (aroma dan warna tepung jamur tiram putih) digunakan untuk menentukan umur simpan tepung jamur tiram putih. Metode pendugaan umur simpan yang digunakan yaitu metode akselerasi (penyimpanan dipercepat) dengan metode Arrhenius (kinetika reaksi). Analisis penentuan umur simpan tepung jamur tiram putih menggunakan simulasi metode akselerasi model Arrhenius dengan bantuan program software Microsoft Excel. Simulasi menggunakan rumus perhitungan berdasarkan model terpilih selanjutnya dirancang dalam bahasa pemograman. Program secara umum terdiri atas lima bagian utama yaitu : 1) Pemilihan jenis produk, 2) Pengumpulan data-data produk, 3) Perhitungan parameter mutu uji, 4) Perhitungan slope kurva persamaan linier, dan 5) Penentuan umur simpan (Kusnandar et al, 2010).

\section{HASIL DAN PEMBAHASAN}

Perubahan Mutu Tepung Jamur Tiram Putih Selama Penyimpanan. Tepung jamur tiram putih dalam kemasan polietilen dengan ketebalan $0.03 \mathrm{~mm}$ mengalami perubahan kadar air, kadar asam lemak bebas, kadar protein, aroma tepung, dan warna tepung selama penyimpanan pada suhu $30^{\circ} \mathrm{C}, 40^{\circ} \mathrm{C}$, dan $50^{\circ} \mathrm{C}$.

Kadar Air. Berdasarkan Gambar 1, tepung jamur tiram putih yang dikemas dengan plastik polietilen dan disimpan pada suhu $40^{\circ} \mathrm{C}$ dan $50^{\circ} \mathrm{C}$ cenderung mengalami penurunan kadar air selama penyimpanan dari $8.52 \%$ menjadi $6.46 \%$ pada suhu $40^{\circ} \mathrm{C}$ dan $3.75 \%$ pada suhu $50^{\circ} \mathrm{C}$, sebaliknya penyimpanan pada suhu $30^{\circ} \mathrm{C}$ menunjukkan kecenderungan peningkatan kadar air dari 8.52\% menjadi 10.14\%.

Hasil penelitian ini sejalan dengan hasil penelitian Susilo (2012) tentang pendugaan umur simpan bahan makanan campuran (BMC) dari tepung sukun dan tepung kacang benguk germinasi pada kemasan plastik polietilen dengan metode akselerasi. Dilaporkan bahwa penyimpanan $\mathrm{BMC}$ pada suhu $30^{\circ} \mathrm{C}$ cenderung mengalami peningkatan kadar air, sedangkan penyimpanan pada suhu $40^{\circ} \mathrm{C}$ dan $50^{\circ} \mathrm{C}$ mengalami penurunan kadar air. Peningkatan kadar air bahan dalam kemasan selama penyimpanan diduga dipengaruhi oleh permeabilitas bahan kemasan terhadap uap air, sifat higroskopis bahan pangan yang dikemas, dan tingkat kelembaban udara lingkungan terhadap produk pangan. 
Astuti, S. dkk : Pendugaan Umur Simpan Tepung Jamur Tiram Putih (Pleurotus ostreatus).

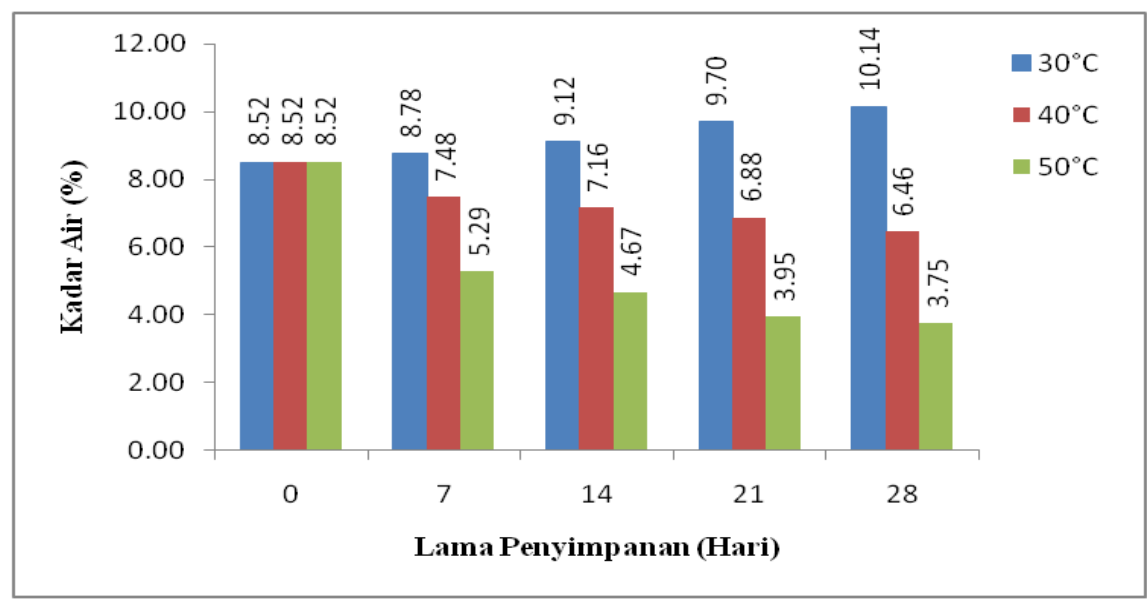

Gambar 1. Histogram hubungan antara lama penyimpanan tepung jamur tiram putih dengan kadar air pada suhu $30^{\circ} \mathrm{C}, 40^{\circ} \mathrm{C}$, dan $50^{\circ} \mathrm{C}$ dalam kemasan polietilen

Tepung memiliki sifat higroskopis yaitu bersifat mudah menyerap air dari lingkungannya untuk mencapai kondisi kesetimbangan. Keberadaan uap air yang terperangkap dalam kemasan akibat perenggangan pori-pori film plastik polietilen karena perlakuan penyimpanan pada suhu $30^{\circ} \mathrm{C}$ menyebabkan kadar air dalam bahan dapat bertambah dan berkurang. Selain itu, perbedaan kelembaban lingkungan dengan sampel tepung menyebabkan perbedaan tekanan parsial uap air. Tekanan parsial uap air yang lebih besar dari lingkungan menyebabkan uap air dari lingkungan pindah ke dalam sampel tepung (Shahzadi et al, 2005; Wijaya, 2007; Mustafidah dan Widjanarko, 2015), sehingga kadar air tepung jamur tiram putih pada suhu penyimpanan $30^{\circ} \mathrm{C}$ mengalami peningkatan.

Tepung jamur tiram putih yang disimpan pada suhu $40^{\circ} \mathrm{C}$ dan $50^{\circ} \mathrm{C}$ cenderung mengalami penurunan kadar air. Berdasarkan penelitian Lestari (2010), pengemasan tepung kentang atlantik dengan plastik polietilen juga mengalami penurunan pada suhu $40^{\circ} \mathrm{C}$. Plastik LDPE memiliki permeabilitas uap air sebesar 800 cc/detik. $\mathrm{cm}^{2}$, $\mathrm{cmHg}$ pada suhu $25^{\circ} \mathrm{C}$, sedangkan permeabilitas $\mathrm{O}_{2}$ plastik polietilen lebih besar dibandingkan polipropilen. Permeabilitas gas plastik polietilen sebesar $55 \mathrm{cc} /$ detik. $\mathrm{cm}^{2}, \mathrm{cmHg}$ pada suhu $30{ }^{\circ} \mathrm{C}$ (Ashley, 1985). Penurunan kadar air pada tepung jamur tiram putih yang disimpan pada suhu $40^{\circ} \mathrm{C}$ dan $50^{\circ} \mathrm{C}$ dalam kemasan plastik polietilen diduga karena semakin tinggi suhu penyimpanan, kandungan air pada bahan akan lebih cepat menguap. Permeabilitas kemasan yang cukup besar terhadap uap air mengakibatkan uap air dan udara mudah keluar masuk melalui kemasan sehingga dapat mempengaruhi mutu produk yang disimpan. Menurut Marinos et al, 1995; Sokhansanj dan Jayas, 1995), apabila bahan padat yang basah dibiarkan berhubungan dengan udara kering di sekitarnya, maka air akan berpindah dari bahan tersebut ke fasa udara. Hal ini terjadi karena tekanan uap air di udara lebih kecil daripada tekanan uap air cairan di padatan. Jika tekanan parsial uap air di udara sama dengan tekanan parsial uap air cairan di padatan, maka dikatakan bahwa kandungan air bahan tersebut merupakan kandungan air kesetimbangan atau equilibrium moisture content (EMC).

Kadar Asam Lemak Bebas. Berdasarkan Gambar 2, kadar asam lemak bebas tepung jamur tiram putih dalam kemasan plastik polietilen dan disimpan pada suhu $30^{\circ} \mathrm{C}, 40^{\circ} \mathrm{C}$, dan $50^{\circ} \mathrm{C}$ cenderung mengalami peningkatan selama penyimpanan. Kadar asam lemak bebas tepung jamur tiram putih pada suhu penyimpanan $30^{\circ} \mathrm{C}$ selama 28 hari mengalami peningkatan dari $0.46 \%$ menjadi $1.02 \%$, pada suhu penyimpanan $40^{\circ} \mathrm{C}$ mengalami peningkatan dari $0.46 \%$ menjadi $0.91 \%$, dan suhu penyimpanan $50^{\circ} \mathrm{C}$ meningkat dari $0.46 \%$ menjadi $0.86 \%$.

Kadar asam lemak bebas tepung jamur tiram putih cenderung meningkat diduga disebabkan terjadi hidrolisis komponen lemak yang terdapat pada tepung jamur tiram putih menjadi asam lemak bebas dan air. Reaksi ini dipercepat dengan adanya faktor-faktor seperti suhu, kadar air, keasaman dan enzim. Semakin lama 
reaksi ini berlangsung, semakin banyak kadar asam lemak bebas yang terbentuk. Peningkatan asam lemak bebas menunjukkan terjadinya kerusakan lemak pada tepung jamur tiram putih sebagai hasil hidrolisis lemak. Hal ini sejalan dengan pernyataan Putri et al, (2016), uap air menyebabkan terjadinya proses hidrolisis lemak/minyak menjadi asam lemak bebas pada produk pangan sehingga kadar lemak menurun. Asam lemak bebas dalam bahan pangan digunakan sebagai indikator terjadinya ketengikan suatu produk yang menghasilkan rasa dan bau yang tidak disukai.

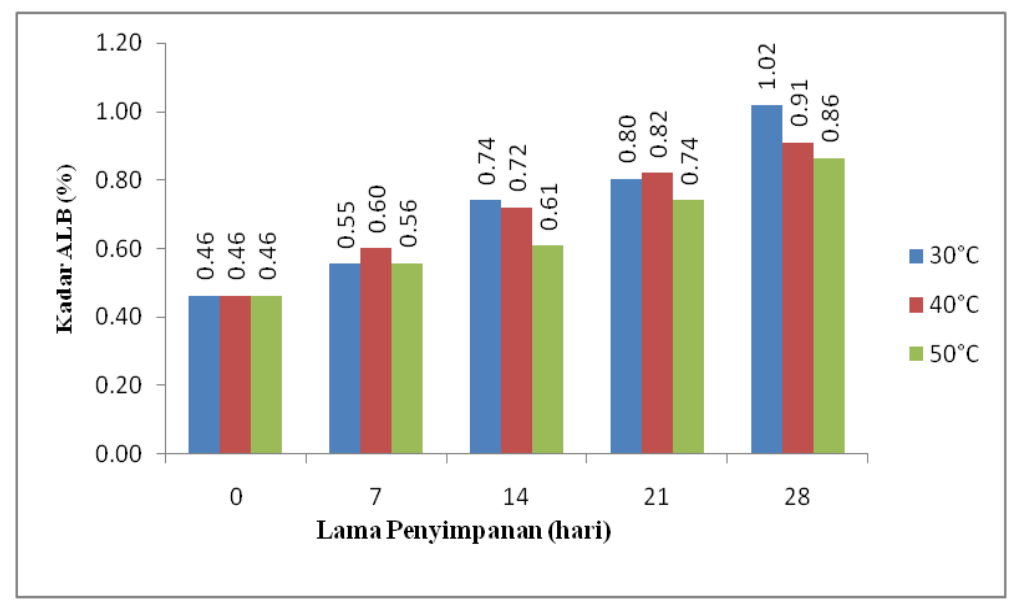

Gambar 2. Histogram hubungan antara lama penyimpanan tepung jamur tiram putih dengan kadar asam lemak bebas pada suhu $30^{\circ} \mathrm{C}, 40^{\circ} \mathrm{C}$, dan $50^{\circ} \mathrm{C}$ dalam kemasan polietilen

Kadar asam lemak bebas tepung jamur tiram putih selama penyimpanan cenderung meningkat pada ketiga suhu penyimpanan $30^{\circ} \mathrm{C}, 40^{\circ} \mathrm{C}$, dan $50^{\circ} \mathrm{C}$. Berdasarkan Gambar 2, peningkatan kadar asam lemak bebas pada suhu penyimpanan $30^{\circ} \mathrm{C}$ lebih besar dibanding suhu $40^{\circ} \mathrm{C}$ dan $50^{\circ} \mathrm{C}$. Hasil ini sejalan dengan data kadar air tepung jamur tiram putih, di mana penyimpanan pada suhu $30^{\circ} \mathrm{C}$ menghasilkan kadar air tepung jamur tiram putih yang lebih tinggi dibanding penyimpanan suhu $40^{\circ} \mathrm{C}$ dan $50^{\circ} \mathrm{C}$. Sifat tepung jamur tiram putih yang higroskopis menyebabkan kadar air pada suhu penyimpanan $30^{\circ} \mathrm{C}$ relatif meningkat sehingga menyebabkan peningkatan kadar asam lemak bebas hasil hidrolisis air yang lebih tinggi dibanding penyimpanan pada suhu $40^{\circ} \mathrm{C}$ dan $50^{\circ} \mathrm{C}$.

Kadar Protein. Berdasarkan Gambar 3, secara deskriptif kadar protein tepung jamur tiram putih mengalami perubahan selama penyimpanan. Perubahan kadar protein tepung jamur tiram putih dalam kemasan plastik polietilen ketebalan $0.03 \mathrm{~mm}$ dan disimpan pada suhu $30^{\circ} \mathrm{C}, 40^{\circ} \mathrm{C}$, dan $50^{\circ} \mathrm{C}$ selama 28 hari mengalami penurunan dari $28.15 \%$ menjadi $23.69 \%$ pada suhu penyimpanan $30^{\circ} \mathrm{C}, 22.32 \%$ pada suhu penyimpanan $40^{\circ} \mathrm{C}$, dan $21.16 \%$ pada suhu penyimpanan $50^{\circ} \mathrm{C}$.

Gambar 3 menunjukkan bahwa tepung jamur tiram putih yang dikemas plastik polietilen mengalami penurunan kadar protein pada semua perlakuan suhu penyimpanan. Kadar protein tepung jamur tiram putih yang relatif menurun selama penyimpanan suhu $30^{\circ} \mathrm{C}, 40^{\circ} \mathrm{C}$, dan $50^{\circ} \mathrm{C}$ diduga akibat terjadi reaksi Maillard. Reaksi Maillard adalah reaksi antara karbohidrat, khususnya gula pereduksi dengan gugus amina primer dari protein. Hasil reaksi tersebut menghasilkan melanoidin dan premelanoidin. Produk melanoidin berwarna coklat gelap, sedangkan produk premelanoidin berwarna lebih terang dan berat molekulnya lebih rendah (Hurrel, 1984). Terjadinya perubahan warna coklat bisa dikehendaki atau menjadi pertanda penurunan mutu produk. Reaksi Maillard berpengaruh terhadap aroma, rasa dan warna produk yang diolah yang berakibat pada penurunan nilai gizi. Polimer akhir hasil reaksi Maillard yang berwarna coklat telah diketahui sifat fisik dan kimianya (Arsa, 2016). Suhu dan waktu pemanasan merupakan faktor-faktor yang mempengaruhi terjadinya reaksi Maillard, di mana semakin lama waktu pemanasan dan semakin tinggi suhu pemanasan, maka peluang terjadinya reaksi Maillard akan semakin tinggi sehingga penurunan nilai gizi semakin cepat (Eriksson, 1981). 
Menurut Hariyadi dan Andarwulan (2006), laju reaksi kimia akan semakin cepat pada suhu yang lebih tinggi, sehingga penurunan mutu produk semakin cepat terjadi. Hal ini sejalan dengan hasil penelitian, di mana suhu penyimpanan $50^{\circ} \mathrm{C}$ relatif menurunkan kadar protein tepung jamur tiram lebih tinggi dibanding suhu penyimpanan $30^{\circ} \mathrm{C}$ dan $40^{\circ} \mathrm{C}$.

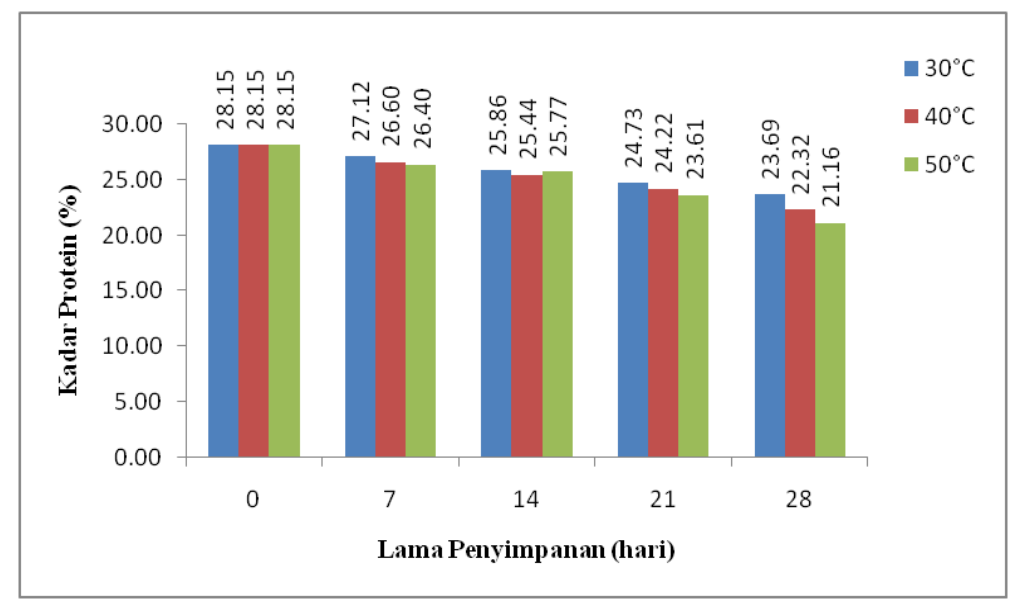

Gambar 3. Histogram hubungan antara lama penyimpanan tepung jamur tiram putih dengan kadar protein pada suhu $30^{\circ} \mathrm{C}, 40^{\circ} \mathrm{C}$, dan $50^{\circ} \mathrm{C}$ dalam kemasan polietilen

Uji Sensori Tepung Jamur Tiram Putih. Pengujian sensori tepung jamur tiram putih dilakukan oleh 25 orang panelis semi terlatih dengan uji skoring. Uji skoring biasa digunakan untuk mengidentifikasi sifat-sifat sensori pada produk untuk mendapatkan informasi mutu suatu produk. Pada uji sensori ini, karakteristik sifatsifat sensori yang digunakan untuk mengetahui mutu tepung jamur tiram putih adalah warna dan aroma.

Aroma. Secara deskriptif aroma tepung jamur tiram putih dalam kemasan plastik polietilen ketebalan $0.03 \mathrm{~mm}$ selama penyimpanan 28 hari pada suhu $30^{\circ} \mathrm{C}, 40^{\circ} \mathrm{C}$, dan $50^{\circ} \mathrm{C}$ dan dilakukan dengan uji skoring mengalami perubahan (Gambar 4). Pada awal penyimpanan, tepung jamur tiram putih belum mengalami perubahan aroma. Pada penyimpanan hari ke-7, skor aroma tepung jamur tiram putih mengalami penurunan pada setiap suhu penyimpanan. Pada penyimpanan tepung jamur tiram putih suhu 30oC, skor aroma sebesar 5.07 (off flavor mulai tercium tetapi sangat lemah); pada suhu $40^{\circ} \mathrm{C}$, skor aroma sebesar 5.9 (diduga ada off flavor tetapi belum tercium); sedangkan suhu $50^{\circ} \mathrm{C}$ memiliki skor sebesar 6.03 (diduga ada off flavor tetapi belum tercium). Pada penyimpanan hari ke-14, aroma tepung jamur tiram putih mengalami penurunan pada suhu $40^{\circ} \mathrm{C}$ dan $50^{\circ} \mathrm{C}$ dengan skor 5.33 dan 5.62, sedangkan suhu $30^{\circ} \mathrm{C}$ turun menjadi 4.27 (off flavor tercium lemah).

Pada minggu ketiga yaitu hari ke-21, skor aroma tepung pada suhu $30^{\circ} \mathrm{C}$ sebesar 3.87 (off flavor tercium lemah), sedangkan pada suhu $40^{\circ} \mathrm{C}$ skor turun menjadi 4.65 . Pada suhu penyimpanan $50^{\circ} \mathrm{C}$ skor turun menjadi 5.07. Pada minggu terakhir atau hari ke-28, skor tepung pada suhu penyimpanan $30^{\circ} \mathrm{C}$ sebesar 3.70 (off flavor tercium lemah), suhu penyimpanan $40^{\circ} \mathrm{C}$ skor aroma sebesar 3.90 , sedangkan suhu penyimpanan $50^{\circ} \mathrm{C}$ skor sebesar 4.42 (off flavor tercium lemah).

Penurunan aroma tepung jamur tiram putih pada ketiga suhu penyimpanan menunjukkan bahwa tepung jamur tiram putih mengalami penyimpangan aroma. Penyimpangan aroma diamati melalui perubahan aroma tepung jamur tiram putih yang mengalami off flavor atau tengik. Salah satu faktor penyebab terjadinya off flavor atau ketengikan adalah asam lemak bebas pada tepung jamur tiram putih. Asam lemak bebas menghasilkan bau yang menyimpang, sehingga hal ini menyebabkan panelis kurang menyukai aroma tepung jamur tiram pada ketiga suhu selama penyimpanan. Dalam bahan pangan, kadar asam lemak bebas dengan konsentrasi tinggi tidak diinginkan. 


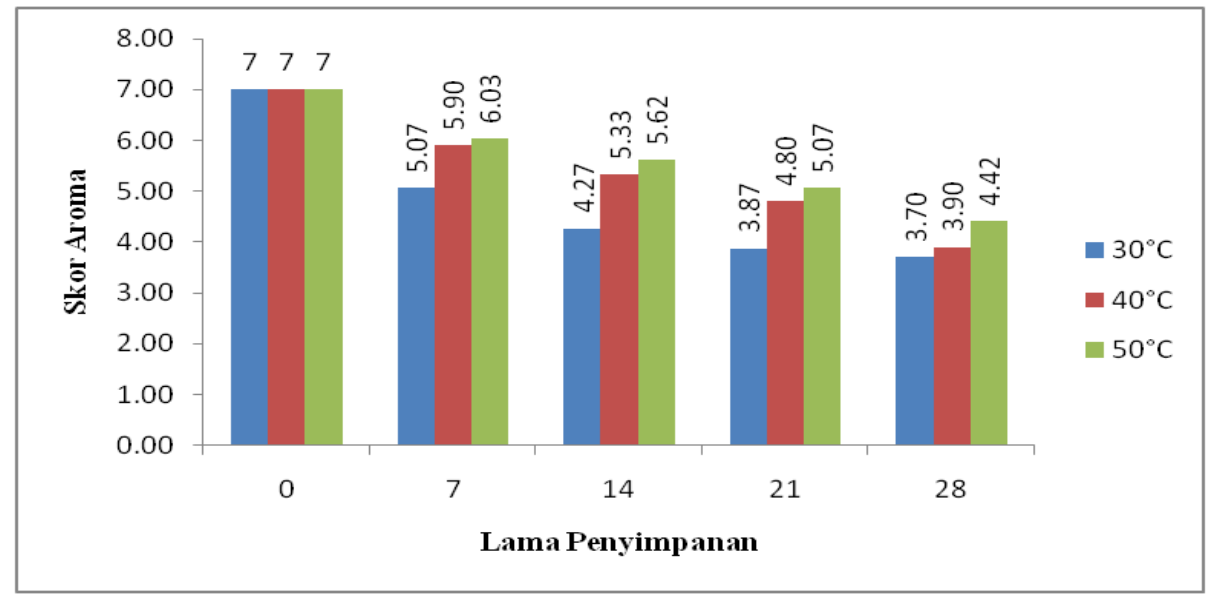

Gambar 4. Histogram hubungan antara lama penyimpanan tepung jamur tiram putih dengan skor aroma tepung jamur tiram putih

Peningkatan kadar asam lemak bebas disebabkan terjadinya reaksi hidrolisa lemak sehingga asam lemak bebas akan mudah menguap, produk berbau tengik, dan menyebabkan rasa tidak enak pada produk sehingga mengakibatkan mutu produk menurun (Swastika, 2009). Berdasarkan data hasil penelitian, kadar asam lemak bebas (ALB) berpengaruh terhadap off flavor tepung jamur tiram putih dalam kemasan plastik polietilen. Pada suhu penyimpanan $30^{\circ} \mathrm{C}, 40^{\circ} \mathrm{C}$, dan $50^{\circ} \mathrm{C}$, kadar asam lemak bebas tepung jamur tiram putih mengalami peningkatan dengan semakin lama penyimpanan untuk ketiga suhu (Gambar 2). Suhu penyimpanan $30^{\circ} \mathrm{C}$ memiliki kadar ALB yang paling tinggi. Peningkatan kadar ALB pada suhu $30^{\circ} \mathrm{C}$ yang lebih tinggi mengakibatkan penyimpangan aroma sehingga skor penerimaan aroma pada suhu penyimpanan $30^{\circ} \mathrm{C}$ lebih rendah dibanding kedua suhu penyimpanan lainnya. Hal ini menunjukkan bahwa off flavor semakin tercium apabila kadar ALB pada tepung jamur tiram putih semakin meningkat.

Warna. Secara deskriptif warna tepung jamur tiram putih dalam kemasan plastik polietilen ketebalan $0.03 \mathrm{~mm}$ selama penyimpanan 28 hari pada suhu $30^{\circ} \mathrm{C}, 40^{\circ} \mathrm{C}$, dan $50^{\circ} \mathrm{C}$ mengalami perubahan (Gambar 5). Pada awal penyimpanan, tepung jamur tiram putih belum mengalami perubahan warna. Pada penyimpanan hari ke-7, skor warna tepung jamur tiram putih mengalami penurunan pada setiap suhu penyimpanan. Penyimpanan tepung jamur tiram putih pada suhu $30^{\circ} \mathrm{C}$ dan $40^{\circ} \mathrm{C}$, memiliki skor warna masing-masing sebesar 5.27 dan 5.17 (warna normal sedikit lebih coklat), sedangkan suhu $50^{\circ} \mathrm{C}$ memiliki skor 4.87 (mendekati normal sedikit lebih coklat). Pada penyimpanan hari ke-14, warna tepung jamur tiram putih mengalami penurunan, masing-masing pada suhu $30^{\circ} \mathrm{C}$ dan $40^{\circ} \mathrm{C}$ dengan skor 5.09 dan 5.00, sedangkan suhu $50^{\circ} \mathrm{C}$ turun menjadi 4.28 . Pada minggu ketiga yaitu hari ke-21, skor tepung pada suhu $30^{\circ} \mathrm{C}$ sebesar 5.05 , pada suhu $40^{\circ} \mathrm{C}$ skor turun menjadi 4.59; dan pada suhu penyimpanan $50^{\circ} \mathrm{C}$ skor turun menjadi 3.57 (warna lebih coklat). Pada minggu terakhir atau hari ke-28, skor tepung pada suhu penyimpanan $30^{\circ} \mathrm{C}$ sebesar 5 (warna tepung jamur tiram putih normal sedikit lebih coklat); suhu $40^{\circ} \mathrm{C}$ skor warna sebesar 4.28.; sedangkan skor warna suhu penyimpanan $50^{\circ} \mathrm{C}$ sebesar 3.07 (warna tepung jamur tiram putih menjadi lebih coklat). Perubahan warna tepung jamur tiram putih selama penyimpanan sejalan dengan data kadar protein, di mana semakin rendah kadar protein tepung jamur tiram selama penyimpanan, warna tepung jamur tiram putih menjadi semakin coklat gelap. Gambar 5 menunjukkan bahwa nilai skor terendah warna tepung jamur tiram putih pada akhir penyimpanan atau hari ke-28 diperoleh pada suhu penyimpanan $50^{\circ} \mathrm{C}$ dengan skor 3.07 (lebih coklat). Skor 3 merupakan titik kritis, di mana panelis mulai kurang menerima tepung jamur tiram putih yang dikemas plastik polietilen. 


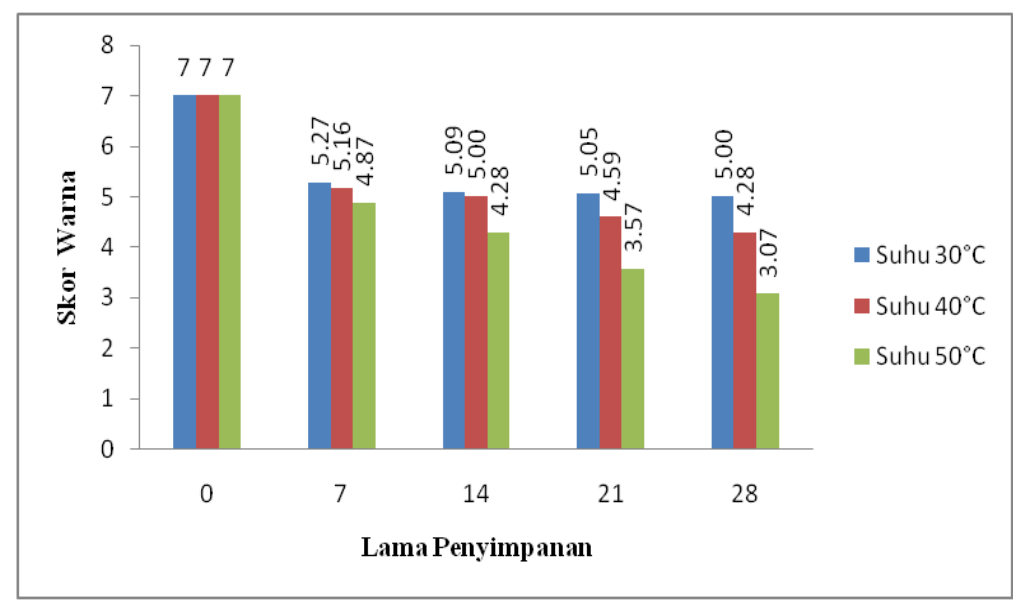

Gambar 5. Histogram hubungan antara lama penyimpanan tepung jamur tiram putih dengan skor warna tepung jamur tiram putih

Perubahan warna coklat pada tepung jamur tiram putih diakibatkan oleh reaksi Mailard. Reaksi Maillard adalah reaksi yang terjadi antara karbohidrat, khususnya gula pereduksi dengan gugus amina primer. Reaksi Maillard merupakan reaksi antara gugus amino dari protein dengan suatu aldosa atau ketosa membentuk senyawa basa schiff, kemudian terjadi perubahan menurut reaksi Amadori menjadi amino ketosa. Degradasi reaksi Amadori membentuk turunan furfuraldehid menghasilkan reaksi antara metil $\alpha$-dikarbonil dan $\alpha$-dikarboksil. Polimerisasi senyawa aldehid tersebut menghasilkan senyawa melanoidin dan premelanoidin. Produk melanoidin berwarna coklat gelap, sedangkan produk premelanoidin berwarna lebih terang dan berat molekulnya lebih rendah (Hurrel, 1984). Hasil reaksi tersebut (senyawa melanoidin dan premelanoidin) menghasilkan produk pangan berwarna coklat yang dijadikan sebagai indikasi penurunan mutu (Arsa, 2016).

Penentuan Umur Simpan Tepung Jamur Tiram Putih. Menurut Koswara dan Kusnandar (2004), penentuan umur simpan dilihat dari nilai korelasi $\left(R^{2}\right)$. Semakin besar nilai korelasi $\left(R^{2}\right)$ menunjukkan semakin cepat terjadi penurunan pada parameter mutu atau kerusakan produk, sehingga pendugaan umur simpan didasarkan pada nilai korelasi $\left(\mathrm{R}^{2}\right)$ yang terbesar. Kriteria tersebut dapat dilihat pada Tabel 1.

Tabel 1 menunjukkan bahwa laju perubahan mutu tepung jamur tiram putih dalam kemasan plastik polietilen ketebalan $0.03 \mathrm{~mm}$ berada pada model reaksi ordo nol. Pendugaan umur simpan pada produk tepung jamur tiram putih dilakukan melalui pemilihan orde reaksi produk tersebut. Perubahan mutu produk dapat berlangsung secara konstan atau tidak. Jika berlangsung secara konstan, maka perubahannya mengikuti kurva linier dan menunjukkan orde reaksi nol. Akan tetapi jika perubahan mutu tidak berlangsung secara konstan maka perubahan mutunya mengikuti kurva eksponensial dan menunjukkan orde 1. Orde reaksi dipilih dari nilai koefisien korelasi $\left(\mathrm{R}^{2}\right)$ yang lebih besar antara kurva linier dan eksponensial (Bind, 2010). Penetapan kinetika reaksi ordo nol pada pendugaan umur simpan tepung jamur tiram putih karena hasil penelitian menunjukkan bahwa nilai korelasi $\left(\mathrm{R}^{2}\right)$ lebih tinggi dibandingkan ordo satu.

Pada pendugaan umur simpan tepung jamur tiram putih, kadar protein dipilih sebagai parameter penentuan umur simpan. Hal ini disebabkan nilai korelasi $\left(\mathrm{R}^{2}\right)$ kadar protein pada ordo reaksi nol memiliki nilai paling besar dibanding parameter mutu lainnya sehingga penentuan umur simpan tepung jamur tiram putih berdasarkan ordo reaksi nol. Parameter kadar asam lemak bebas juga memiliki nilai korelasi $\left(\mathrm{R}^{2}\right)$ yang mendekati nilai parameter kadar protein. Namun karena protein merupakan salah satu komponen gizi dominan penyusun tepung jamur tiram putih, parameter kadar protein dipilih sebagai parameter penentuan umur simpan tepung jamur tiram putih yang dikemas dalam plastik polietilen dengan ketebalan $0.03 \mathrm{~mm}$. 
Jurnal Penelitian Pertanian Terapan

Tabel 1. Plot hubungan suhu penyimpanan dengan parameter mutu

\begin{tabular}{|c|c|c|c|c|c|c|c|}
\hline \multirow{2}{*}{$\begin{array}{l}\text { Parameter } \\
\text { Mutu }\end{array}$} & \multirow{2}{*}{ suhu ${ }^{\circ} \mathrm{C}$} & \multicolumn{2}{|c|}{ Ordo 0} & \multicolumn{2}{|c|}{ Ordo 1} & \multirow[b]{2}{*}{$\begin{array}{l}\text { Intercept } \\
\text { (b) }\end{array}$} & \multirow[b]{2}{*}{$\begin{array}{l}\text { Korelasi } \\
\left(\mathrm{R}^{2}\right)\end{array}$} \\
\hline & & $\begin{array}{l}\text { Slope } \\
\text { (k) }\end{array}$ & $\begin{array}{l}\text { Intercept } \\
\text { (b) }\end{array}$ & $\begin{array}{l}\text { Korelasi } \\
\left(\mathrm{R}^{2}\right)\end{array}$ & $\begin{array}{l}\text { Slope } \\
\text { (k) }\end{array}$ & & \\
\hline \multicolumn{8}{|l|}{ Kadar Air } \\
\hline & 30 & 0.059 & 8.419 & 0.98 & 0.006 & 2.133 & 0.985 \\
\hline & 40 & -0.067 & 8.245 & 0.922 & -0.009 & 2.111 & 0.942 \\
\hline & 50 & -0.155 & 7.408 & 0.79 & -0.027 & 1.995 & 0.868 \\
\hline rata-rata & & -0.054 & 8.024 & 0.897 & -0.010 & 2.080 & 0.932 \\
\hline $1 / \mathrm{T}$ & & -4687 & 12.52 & 0.833 & -7321 & 18.92 & 0.924 \\
\hline \multicolumn{8}{|l|}{ ALB } \\
\hline & 30 & 0.019 & 0.444 & 0.974 & 0.027 & -0.761 & 0.980 \\
\hline & 40 & 0.015 & 0.479 & 0.992 & 0.023 & -0.713 & 0.966 \\
\hline & 50 & 0.014 & 0.449 & 0.978 & 0.021 & -0.765 & 0.989 \\
\hline Rata-rata & & 0.016 & 0.457 & 0.981 & 0.024 & -0.746 & 0.978 \\
\hline $1 / \mathrm{T}$ & & 1502 & -8.947 & 0.919 & 1233 & -7.691 & 0.980 \\
\hline \multicolumn{8}{|l|}{ Protein } \\
\hline & 30 & -0.161 & 28.25 & 0.998 & -0.006 & 3.34 & 0.998 \\
\hline & 40 & -0.2 & 28.25 & 0.979 & -0.008 & 3.341 & 0.987 \\
\hline & 50 & -0.239 & 28.27 & 0.975 & -0.009 & 3.351 & 0.951 \\
\hline Rata-rata & & -0.200 & 28.257 & 0.984 & -0.008 & 3.344 & 0.979 \\
\hline $1 / \mathrm{T}$ & & -1934 & 4.562 & 0.998 & -1992 & 1.484 & 0.952 \\
\hline \multicolumn{8}{|l|}{ Aroma } \\
\hline & 30 & -0.111 & 6.341 & 0.836 & -0.022 & 1.845 & 0.89 \\
\hline & 40 & -0.104 & 6.845 & 0.982 & -0.019 & 1.939 & 0.982 \\
\hline & 50 & -0.087 & 6.852 & 0.981 & -0.015 & 1.934 & 0.988 \\
\hline Rata-rata & & -0.101 & 6.679 & 0.933 & -0.019 & 1.906 & 0.953 \\
\hline $1 / \mathrm{T}$ & & 1185 & -6.092 & 0.923 & 1868 & -9.968 & 0.976 \\
\hline \multicolumn{8}{|l|}{ Warna } \\
\hline & 30 & -0.06 & 6.323 & 0.607 & -0.01 & 1.835 & 0.624 \\
\hline & 40 & -0.085 & 6.41 & 0.804 & -0.015 & 1.855 & 0.852 \\
\hline & 50 & -0.131 & 6.391 & 0.9 & -0.028 & 1.867 & 0.96 \\
\hline Rata-rata & & -0.092 & 6.375 & 0.770 & -0.018 & 1.852 & 0.812 \\
\hline $1 / \mathrm{T}$ & & -3815 & 9.761 & 0.993 & -5025 & 11.93 & 0.98 \\
\hline
\end{tabular}

Penentuan umur simpan tepung jamur tiram putih berdasarkan parameter kadar protein dihitung menggunakan persamaan regresi linear dari plot nilai $1 / \mathrm{T}$ dan $\mathrm{ln} \mathrm{k}$ pada parameter mutu tepung jamur tiram putih. Hasil persamaan tersebut ditransformasi ke dalam persamaan Arrhenius dan dimasukkan ke dalam persamaan kinetika reaksi berdasarkan ordo reaksinya, sehingga diperoleh umur simpan tepung jamur tiram putih. Hasil perhitungan umur simpan tepung jamur tiram putih berdasarkan beberapa parameter penurunan mutu pada berbagai suhu penyimpanan $\left(30^{\circ} \mathrm{C}, 40^{\circ} \mathrm{C}\right.$, dan $\left.50^{\circ} \mathrm{C}\right)$ dapat dilihat pada Tabel 2.

Penentuan umur simpan tepung jamur tiram putih berdasarkan parameter kadar protein yaitu umur simpan pada suhu $30^{\circ} \mathrm{C}$ selama 130.672 hari (4.3 bulan) (Tabel 2). Suhu $30^{\circ} \mathrm{C}$ dipilih karena mendekati suhu ruang yang umumnya digunakan untuk menyimpan produk berbentuk tepung. Suhu penyimpanan merupakan faktor yang berpengaruh terhadap perubahan mutu produk pangan. Walaupun kadar asam lemak bebas tepung 
Astuti, S. dkk : Pendugaan Umur Simpan Tepung Jamur Tiram Putih (Pleurotus ostreatus)..........

jamur tiram putih pada suhu $30^{\circ} \mathrm{C}$ memiliki umur simpan lebih lama yaitu selama 191.206 hari (6.37 bulan ), namun parameter kadar asam lemak bebas tidak dipilih sebagai parameter umur simpan tepung jamur tiram putih karena apabila parameter asam lemak bebas yang dipilih, maka kandungan protein sebagai komponen utama penyusun tepung jamur tiram putih telah mengalami kerusakan.

Tabel 2. Umur simpan tepung jamur tiram putih berdasarkan beberapa parameter penurunan mutu pada berbagai suhu penyimpanan $\left(30^{\circ} \mathrm{C}, 40^{\circ} \mathrm{C}\right.$, dan $\left.50^{\circ} \mathrm{C}\right)$

\begin{tabular}{llllll}
\hline Suhu Penyimpanan & \multicolumn{6}{l}{ Umur Simpan Tepung Jamur Tiram Putih } & & \\
\hline & $\begin{array}{l}\text { Kadar air } \\
\text { (hari) }\end{array}$ & $\begin{array}{l}\text { Kadar FFA } \\
\text { (hari) }\end{array}$ & $\begin{array}{l}\text { Kadar Protein } \\
\text { (hari) }\end{array}$ & $\begin{array}{l}\text { Warna } \\
\text { (hari) }\end{array}$ & $\begin{array}{l}\text { Aroma } \\
\text { (hari) }\end{array}$ \\
\hline $30^{\circ} \mathrm{C}$ & 114.15 & 191.21 & $\mathbf{1 3 0 . 6 7}$ & 67.77 & 35.42 \\
$40^{\circ} \mathrm{C}$ & 69.64 & 224.02 & 106.57 & 45.32 & 40.14 \\
$50^{\circ} \mathrm{C}$ & 42.80 & 259.90 & 88.01 & 31.08 & 45.13 \\
\hline
\end{tabular}

Pada penentuan umur simpan bahan pangan, parameter protein dipilih sebagai parameter kritis dengan melihat penurunan kadar protein pada bahan tersebut. Perubahan sifat bahan pangan akibat reaksi antara gula reduksi dengan asam amino sehingga terjadi reaksi pencoklatan mempengaruhi peneriman konsumen dan menunjukkan penurunan mutu produk (Arsa, 2016). Menurut Herawati (2008), faktor-faktor yang mempengaruhi umur simpan adalah jenis dan karakteristik produk pangan, jenis dan karakteristik bahan kemasan (permeabilitas bahan kemasan terhadap kondisi lingkungan), dan kondisi atmosfer terutama suhu kelembaban di mana kemasan dapat bertahan selama digunakan dan sebelum digunakan. Oleh karena itu, bahan pengemas suatu produk harus dipilih yang memiliki permeabilitas yang rendah dan tahan terhadap suhu penyimpanan.

Berdasarkan pendugaan umur simpan dalam plastik polietilen yang telah dilakukan beberapa peneliti, Bambang et al, (2011) melaporkan bahwa tepung jagung kuning instan dalam kemasan plastik polietilen (PE) ketebalan 0,05 mm memiliki umur simpan selama 107 hari, sedangkan tepung jagung putih instan dalam kemasan plastik Polietilen (PE) ketebalan 0,05 mm selama 73 hari. Hasil penelitian (Lestari, 2010) menunjukkan bahwa umur simpan tepung kentang atlantik dalam kemasan LDPE pada suhu $30^{\circ} \mathrm{C}$ selama116 hari (3 bulan 27 hari).

\section{KESIMPULAN}

Umur simpan tepung jamur tiram putih dalam kemasan plastik polietilen ketebalan $0.03 \mathrm{~mm}$ menggunakan metode Arrhenius ditetapkan pada suhu $30^{\circ} \mathrm{C}$ berdasarkan parameter kadar protein ordo reaksi nol, yaitu selama 130.67 hari (4.3 bulan).

Tepung jamur tiram putih dalam kemasan plastik polietilen ketebalan $0.03 \mathrm{~mm}$ selama penyimpanan suhu $30^{\circ} \mathrm{C}, 40^{\circ} \mathrm{C}$, dan $50^{\circ} \mathrm{C}$ cenderung mengalami penurunan kadar protein, warna dan aroma, namun mengalami peningkatan kadar asam lemak bebas. Tepung jamur tiram putih dalam kemasan plastik polietilen pada suhu $30^{\circ} \mathrm{C}$ mengalami peningkatan kadar air selama penyimpanan, dan mengalami penurunan kadar air pada penyimpanan suhu $40^{\circ} \mathrm{C}$ dan $50^{\circ} \mathrm{C}$.

\section{DAFTAR PUSTAKA}

AOAC. 2005. Official Methods of Analysis Association of Official Analytical ChemistsNo Title. Edited by Benjamin Franklin Station. Washington.

Ardiansyah, F. Nurainy, dan S. A. 2014. Pengaruh Perlakuan Awal terhadap Karakteristik Kimia dan Organoleptik Tepung Jamur Tiram (Pleurotus oestreatus). Jurnal Teknologi Industri dan Hasil Pertanian, 19(4), pp. 117-126. 
Jurnal Penelitian Pertanian Terapan

Arianto, D. P. dan S. 2009. Karakteristik Jamur Tiram Putih (Pleurotus ostreatus) Selama Penyimpanan. Agroteknos, 20(1), pp. 31-40.

Arpah, M. 2001. Penentuan Kadaluwarsa Produk Pangan. Institut Pertanian Bogor.

Arpah, M. dan R. S. 2000). Evaluasi Model-model Pendugaan Umur Simpan Pangan dari Difusi Hukum Fick Undireksional. Buletin Teknologi dan Industri Pangan, pp. 11:1-11.

Arsa, M. 2016. Proses Pencoklatan (Browning Process) pada Bahan Pangan. Universitas Udayana.

Ashley, R. 1985. Permeability and Plastics Packaging. Polymer Pe. London: Elsevier, J.C. Applied.

Bambang, S.A., W. Atmaka., dan D. R. 2011. Prediksi Umur Simpan Tepung Jagung (Zea mays L.) Instan di dalam Kemasan Plastik. Jurnal Teknologi Hasil Pertanian, 4(2), pp. 74-83.

Bind, L. 2010. Aplikasi Metode Arrhenius dalam Pendugaan Umur Simpan Lada Hijau Kering (Dehydrated Green Pepper). Institut Pertanian Bogor.

Cahyana, Y.A., Muchrodji, dan M. B. 1999. Jamur Tiram. Jakarta: Penebar Swadaya.

Dinas Pertanian Tanaman Pangan dan Hortikultura. 2015. Lampung dalam Angka. Bandar Lampung.

Ellis, M. 1994. The Methodology of Shelf Life Determination. Shelf Life. London: Blackie Academic and Professional Inc.

Eriksson, C. 1981. Maillard Reaction in Food. Chemical, . Oxford: Pergamon Press.

Hafriyanti, Hidayati, dan E. 2008. Kualitas Daging Sapi dengan Kemasan Plastik PE (Polyethylen) dan Plastik PP (Polypropylen) di Pasar Arengka Kota Pekanbaru. Jurnal Peternakan, 5(1), pp. 22-27.

Hariyadi, P. dan N. A. 2006. Perubahan Mutu (Fisik, Kimia dan Mikrobiologi) Produk Pangan selama Pengolahan dan Penyimpanan. Bogor.

Herawati. 2008. Penentuan umur simpan pada produk pangan', Penentuan Umur Simpan Pada Produk Pangan, 27(4), pp. 124-130.

Hurrel, R. 1984. Reaction of Food Protein during Processing and Storage and Their Nutritional Consequences. Developmen. Edited by B. J. F. Hudson. London \& New York: Elseiver Applied Science.

Koswara, S. 2004. Evaluasi Sensori dalam Pendugaan Umur Simpan Produk Pangan. Bogor.

Koswara, S. dan F. K. 2004. Pendugaan Masa Kadaluarsa Produk-Produk Spesifik. Bogor.

Kusnandar, F. 2004. Aplikasi Program Komputer sebagai Alat Bantu Penentuan Umur Simpan Produk Pangan Metode Arrhenius. Bogor.

Kusnandar, F. 2006. Disain Percobaan dalam Penetapan Umur Simpan Produk Pangan dengan Metode ASLT (Model Arrhenius dan Kadar Air Kritis). Bogor.

Kusnandar, F., Adawiyah, D. R. and Fitria, M. 2010. Pendugaan Umur Simpan Produk Biskuit Dengan Metode Akselerasi Berdasarkan Pendekatan Kadar Air Kritis. Jurnal Teknologi dan Industri Pangan, XXI(2), pp. 1-6.

Labuza, T. P. 2000. The search for shelf life. Food Testing \& Analysis, 6(2), pp. 26-36. Available at: Binder 10 Page 44. 
Astuti, S. dkk : Pendugaan Umur Simpan Tepung Jamur Tiram Putih (Pleurotus ostreatus)..........

Laksono, M. A., Bintoro, V. P. and Mulyani, S. 2012. Daya Ikat Air, Kadar Air, Dan Protein Nugget Ayam Yang Disubstitusi Dengan Jamur Tiram Putih (Pleurotus ostreatus). Animal Agriculture Journal, 1(1), pp. 685-696.

Lestari, B. 2010. Perubahan Warna Tepung Kentang Atlantik Selama Penyimpanan dan Pendugaan Umur Simpannya. Institut Pertanian Bogor.

Marinos, D., Kouris, D., dan Z. B. M. 1995. Transport Properties in The Drying of Solid. Handbook o. Edited by A. S. Mujumdar. New York: Marcel Dekker, Inc.

Mustafidah, C. dan S. B. W. 2015. Umur Simpan Minuman Serbuk Berserat dari Tepung Porang (Amorpophallus oncophillus) dan Karagenan melalui Pendekatan Kadar Air Kritis. Jurnal Pangan dan Agroindustri, 3(2), pp. 650-660.

Nurany, F., Sugiharto, R. and Sari, D. W. 2015. Pengaruh Perbandingan Tapioka dan Tepung Jamur (Pleurotus oestreatus) terhadap Volume Pengembangan, Kadar Protein dan Organoleptik Kerupuk Nurainy et al. Teknologi Industri Dan Hasil Pertanian, 20(1), pp. 11-24.

Putri, A.I., Hervelly, dan I. S. N. 2016. Pendugaan Umur Simpan Keripik Tempe yang Dikemas dengan Berbagai Jenis Kemasan dan Disimpan pada Suhu Penyimpanan Berbeda. Universitas Pasundan.

Rus'an. 2007. Pengaruh Penggunaan Tepung Jamur Tiram Putih (Pleurotus ostreatus) terhadap Kadar Protein Sosis. Agroteknos, 4(2), pp. 104-114.

Sánchez, C. 2010. Cultivation of Pleurotus ostreatus and other edible mushrooms. Applied Microbiology and Biotechnology, pp. 1321-1337. doi: 10.1007/s00253-009-2343-7.

Shahzadi, N., M.S. Butt, S.U. Rehman, and K. S. 2005. Chemical Characteristics of Various Composite Flours. International Journal of Agriculture and Biology, 7(1), p. 105-108.

Sokhansanj, S. dan D. S. J. 1995. Drying of Foodstuffs. Handbook o. Edited by A. S. Mujumdar. New York: Marcel Dekker, Inc.

Sudarmadji, S., B. Haryono, dan S. 1997. Prosedur Analisis untuk Bahan Makanan dan Pertanian. Yogyakarta: Liberty.

Susilo, A. 2012. Pendugaan Umur Simpan Bahan Makanan Campuran (BMC) dari Tepung Sukun (Artocarpus communis) dan Tepung Kacang Benguk Germinasi (Mucuna pruriens L.) pada Kemasan Plastik Poliethilen dengan Metode Akselerasi. Universitas Lampung.

Swastika, N. 2009. Stabilisasi Tepung Bekatul Melalui Metode Pengukusan dan Pengeringan Rak serta Pendugaan Umur Simpannya. Institut Pertanian Bogor.

Syarief, R., S. Santausa, dan S. I. 1989. Teknologi Pengemasan Pangan. Bogor.

Syarif, R. dan H. H. 1993. Teknologi Penyimpanan Pangan. Bogor.

Widyastuti, N. and Istini, S. 2004. Optimasi Proses Pengeringan Tepung Jamur Tiram Putih (Pleurotus ostreatus). Jifi.Ffup.Org, 2(I), pp. 8-11. Available at: http://jifi.ffup.org/wpcontent/uploads/2012/03/Netty.Optimasi.pdf.

Wijaya, C. 2007. Pendugaan Umur Simpan Produk Kopi Instan Formula Merk-Z dengan Metode Arrhenius. Institut Pertanian Bogor. 